\title{
Extrapulmonary sites of Pseudomonas aeruginosa in adults with cystic fibrosis
}

\author{
R F H Taylor, D W Morgan, P S Nicholson, I S Mackay, M E Hodson, T L Pitt
}

\begin{abstract}
Background Pseudomonas aeruginosa infection is seldom eradicated in patients with cystic fibrosis despite intensive antipseudomonal treatment. Upper airway sites of infection may contribute to perpetuation of lower airways infection. This study was designed to find out which extrapulmonary sites are infected and whether the strains at these sites are identical to those in the lungs.
\end{abstract}

Methods Sputum and upper airway samples from 42 patients were cultured for $P$ aeruginosa and stool samples from 20 patients were also tested. Nineteen isolates from sputum and extrapulmonary sites from four patients were genotyped with the pCM tox probe.

Results $P$ aeruginosa was isolated from the sputum of 36 patients, 34 of whom had infection in the upper airways. Six of the 20 patients tested were positive for $P$ aeruginosa in the stool. The nasopharynx was colonised in 30 patients, the oropharynx in 29 , the middle meatus in 13 , the external nares in six, and the inferior turbinate in four. Three of four patients tested had the same strain of $P$ aeruginosa (a different one in each individual) in the sputum and the upper airways, and in two of the three the stool isolate was a different strain.

Conclusion Most adults with cystic fibrosis and $P$ aeruginosa pulmonary infection have upper airway reservoirs of the organism and strains from these sites are identical to those in the lungs.

Persistent pulmonary infection with Pseudomonas aeruginosa is common in patients with cystic fibrosis despite intensive antipseudomonal antibiotic treatment. ${ }^{1}$ Failure to eradicate this organism is probably due to an inadequate concentration of antibiotics in the sputum, ${ }^{2}$ though other host and pathogen factors have been suggested. ${ }^{3}$ We postulated that a further mechanism contributing to persistence of $P$ aeruginosa infection was infection of extrapulmonary sites, such as the gastrointestinal tract and the upper airways. These may act as sanctuary sites for $P$ aeruginosa as effective antimicrobial concentrations may not be reached here. ${ }^{4}$ Such reservoirs might reseed the lungs and perpetuate infection. If $P$ aeruginosa is harboured outside the lungs accurate identification of the strain in each patient is required if a relation between extrapulmonary sites and the lungs is to be supported.

We assessed the upper airways clinically, and examined the frequency of colonisation of extrapulmonary sites by $P$ aeruginosa in a cross sectional study of adults with cystic fibrosis. Extrapulmonary isolates were compared with pulmonary strains by genotyping.

\section{Methods}

Forty two patients with cystic fibrosis (23 female; mean age 26 (range 15-66) years) were selected randomly from outpatients. They were asked about current symptoms of nasal obstruction and sinus infection before anterior and posterior rhinoscopy. The presence of nasal polyps, mucus strands, and nasal mucosal hyperaemia was noted. Forced expiratory volume in one second $\left(\mathrm{FEV}_{1}\right)$ was expressed as a percentage of the predicted value. ${ }^{5}$ Sputum was collected after physiotherapy and dry swabs were taken from the inferior turbinate, external nares, middle meatus, oropharynx (tonsillar fossa), and nasopharynx (postnasal space); samples were taken from the middle meatus because the paranasal sinuses drain into this region. Stool samples were returned by 20 patients within 48 hours of the outpatient visit. In 21 patients the upper airways were sampled twice during the nine month study. Twenty seven patients were regularly taking nebulised antipseudomonal antibiotics by mouthpiece.

\section{BACTERIOLOGICAL METHODS}

Sputum was homogenised after dilution with an equal volume of Ringer's solution and then plated $(0 \cdot 1 \mathrm{ml})$ on to Pseudomonas Isolation Agar (PIA: Difco Laboratories, Detroit, Michigan). Upper airway swabs were plated immediately on to King's A agar. ${ }^{6}$ Stools were enriched in acetamide broth ${ }^{7}$ and inoculated similarly. After aerobic incubation at $37^{\circ} \mathrm{C}$ for 48 hours isolates that produced the characteristic pigment pyocyanin were accepted as $P$ aeruginosa. Non-pigmented isolates were identified by the API 20NE system (BioMerieux Ltd, Basingstoke).

\section{TYPING METHODS}

Nineteen isolates from four patients were selected for genotyping. ${ }^{8}$ DNA was extracted from broth cultures ${ }^{9}$ and digested with restriction 
Table 1 Clinical findings in 42 patients with cystic fibrosis

\begin{tabular}{lllll}
\hline $\begin{array}{l}\text { No of } \\
\text { patients }\end{array}$ & $\begin{array}{l}\text { Upper airway } \\
\text { symptoms }\end{array}$ & $\begin{array}{l}\text { Abnormal signs } \\
\text { in upper airways }\end{array}$ & $\begin{array}{l}\text { Mean (range) } \\
\text { FEV } \\
\text { (\% pred) }\end{array}$ & $\begin{array}{l}\text { No of patients with } \\
\text { Paeruginosa in upper } \\
\text { airways }(n=35)\end{array}$ \\
\hline 25 & + & + & $41(15-93)$ & 20 \\
9 & - & + & $37(21-74)$ & 8 \\
7 & - & - & $49(19-93)$ & 6 \\
1 & + & - & 25 & 1 \\
\hline
\end{tabular}

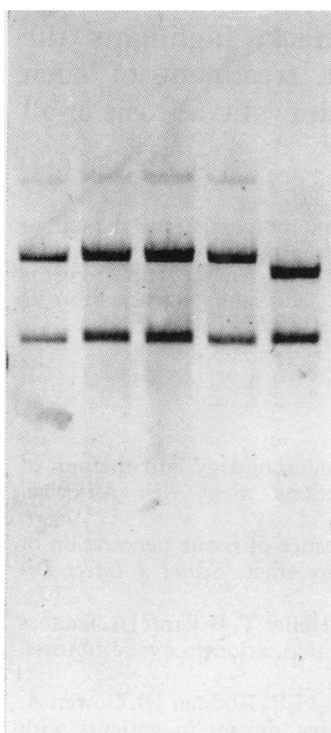

$\begin{array}{lllll}1 & 2 & 3 & 4 & 5\end{array}$

Five isolates of

Psudomonas aeruginosa

from patient $A$, digested with Bg1 II and probed with the pCM-tox plasmid. Sites: 1-sputum;

2-inferior turbinate

3-oropharynx;

4-nasopharynx; 5-stool. endonucleases $X h o 1, B g 1 \mathrm{II}$, and $S a 1 \mathrm{I}$ (Gibco, Uxbridge). After electrophoresis in agarose gel DNA fragments were transferred to a nylon membrane with the aid of the Vacugene system (Pharmacia Ltd, Milton Keynes). Southern blots were probed with a biotin labelled $\mathrm{pCM}$ tox probe $^{1011}$ and hybridisation bands visualised with a Blugene kit (Gibco).

\section{Results}

\section{CLINICAL RESULTS}

Patients fell into four categories according to whether upper airway symptoms and signs were present (table 1). Most (26 of 42) had symptoms of upper airway disease, such as nasal obstruction, discharge, postnasal drip, headaches, and hyposmia, and all but one of these patients and nine symptom free patients had abnormal signs. Of the 34 with abnormal signs, 24 had mucus strands, 22 had nasal mucosal hyperaemia, and 11 had nasal polyps. Seven patients had neither symptoms nor signs of upper airway disease; there was no relation between severity of lung disease and the presence of upper airway disease. The mean $\mathrm{FEV}_{1}$ value was $40 \%$ (range 15-93\%) predicted.

\section{MICROBIOLOGICAL RESULTS}

$P$ aeruginosa was isolated from the sputum of 36 of the 42 patients. Of these, 34 harboured the organism in the upper airways, including six of the seven patients without upper respiratory tract symptoms and signs. The nasopharynx and oropharynx were the most frequently colonised sites (table 2), whereas the inferior turbinate and external nares were mainly free of $P$ aeruginosa. One of the six patients without $P$ aeruginosa in the sputum harboured the organism in an upper airway site, but only in the nasopharynx. Of the 35 patients with $P$ aeruginosa in the upper airways, 25 were taking nebulised antipseudomonal antibiotics regularly. In 21 patients sampled twice the yield of $P$ aeruginos $a$ from the nasopharynx and oropharynx was reproduced in 19 and 17 patients respectively.

$P$ aeruginosa was recovered from more than one upper airway site (table 3) in 26 of 35 patients, though only one patient was colonised at all sites. All but three of the patients who had $P$ aeruginosa in the oropharynx had at least one other site colonised. $P$ aeruginosa was isolated from the stools of six of 20 patients tested and in all six $P$ aeruginosa was cultured from sputum and from two or more upper airway sites. Thirteen patients harboured mucoid strains in the upper airways. These were isolated from the nasopharynx (12 patients), oropharynx (nine), and middle meatus (eight). Symptoms and/or signs of upper airway disease were detected in six of seven patients not infected by $P$ aeruginosa at these sites.

Genotyping (table 4) indicated that the upper airways and sputum of three of four patients were infected by the same strain, which was different in each individual (figure). The stool isolates from two of these patients were distinct from the airway strain.

\section{Discussion}

Our finding that most adults with cystic fibrosis who harbour $P$ aeruginosa in the sputum also have their upper respiratory tract colonised make it clear that $P$ aeruginosa has a proclivity for both the upper and the lower airways. These results contrast with those of a recent study of children with cystic fibrosis, ${ }^{12}$ where upper airway carriage of $P$ aeruginosa correlated poorly with lower respiratory infection; this discrepancy may partly be due to age differences between the populations studied. The absence of upper airway symptoms or signs did not preclude colonisation by $P$ aeruginosa at upper airway sites and most patients with upper airway infection were receiving regular nebulised antibiotics.

Identical strains were found in the upper and lower airways in three of the four patients whose strains were genotyped, thereby raising the possibility of a clinically important association between the sites. A prospective longitudinal study in children is required to determine the initial site of $P$ aeruginosa colonisation in cystic fibrosis. Establishing this and targeting the primary site with antipseudomonal antimicrobials might help to determine whether the extrapulmonary sites are implicated in the initiation of pulmonary

Table 2 Prevalence, distribution, and prevalence of Pseudomonas aeruginosa in the upper airways among 42 patients with cystic fibrosis

\begin{tabular}{|c|c|c|c|c|c|c|}
\hline & \multirow[b]{2}{*}{$\begin{array}{l}\text { No of } \\
\text { patients }\end{array}$} & \multicolumn{5}{|c|}{ Sites sampled } \\
\hline & & $\begin{array}{l}\text { Inferior } \\
\text { turbinate }\end{array}$ & $\begin{array}{l}\text { External } \\
\text { nares }\end{array}$ & Oropharynx & $\begin{array}{l}\text { Middle } \\
\text { meatus }\end{array}$ & Nasopharynx \\
\hline $\begin{array}{l}\text { Upper airway and sputum culture } \\
\text { positive for } P \text { aeruginosa } \\
\text { Upper airway positive and sputum }\end{array}$ & 34 & 4 & 6 & 29 & 13 & 30 \\
\hline culture negative for $P$ aeruginosa & 1 & - & - & - & - & 1 \\
\hline
\end{tabular}

In two patients sputum culture was positive and upper airways negative for $P$ aeruginosa and in five sputum culture was negative and upper airways negative for $P$ aeruginosa. 
Table 3 Location and concurrence of positive sites for Pseudomonas aeruginosa in 35 cystic fibrosis patients

\begin{tabular}{|c|c|c|c|}
\hline $\begin{array}{l}\text { No of } \\
P \text { aeruginosa } \\
\text { positive sites } \\
\text { in the same } \\
\text { patient }\end{array}$ & Upper airway sites & \multicolumn{2}{|c|}{$\begin{array}{l}\text { No of patients positive } \\
\text { for } P \text { aeruginosa }\end{array}$} \\
\hline 1 & $\begin{array}{l}\text { Oropharynx } \\
\text { Middle meatus } \\
\text { Nasopharynx }\end{array}$ & $\begin{array}{l}3 \\
1 \\
5\end{array}$ & Total \\
\hline 2 & $\begin{array}{l}\text { Oropharynx }+ \text { middle meatus } \\
\text { Oropharynx }+ \text { nasopharynx } \\
\text { Middle meatus + nasopharynx }\end{array}$ & $\begin{array}{r}1 \\
10 \\
1\end{array}$ & 12 \\
\hline 3 & $\begin{array}{l}\text { Inferior turbinate or external } \\
\text { nares }+ \text { oropharynx }+ \text { nasopharynx } \\
\text { Oropharynx }+ \text { nasopharynx }+ \\
\text { middle meatus }\end{array}$ & $\begin{array}{l}4 \\
5\end{array}$ & 9 \\
\hline 4 & $\begin{array}{l}\text { Inferior turbinate or external } \\
\text { nares }+ \text { oropharynx }+ \text { nasopharynx } \\
+ \text { middle meatus }\end{array}$ & 4 & 4 \\
\hline 5 & All sites & 1 & 1 \\
\hline Total & & & 35 \\
\hline
\end{tabular}

Table 4 Genotyping of Pseudomonas aeruginosa from selected patients

\begin{tabular}{|c|c|c|}
\hline Patient & Site & Genotype pattern \\
\hline A & $\begin{array}{l}\text { Sputum } \\
\text { Inferior turbinate } \\
\text { Oropharynx } \\
\text { Nasopharynx } \\
\text { Stool }\end{array}$ & $\begin{array}{l}a \\
a \\
a \\
a \\
b\end{array}$ \\
\hline B & $\begin{array}{l}\text { Sputum a } \\
\text { Sputum b } \\
\text { Oropharynx } \\
\text { Nasopharynx } \\
\text { Stool }\end{array}$ & $\begin{array}{l}\text { c } \\
\text { c } \\
\text { c } \\
\text { c } \\
\text { c }\end{array}$ \\
\hline $\mathrm{C}$ & $\begin{array}{l}\text { Sputum 1 } \\
\text { Sputum 2 } \\
\text { Oropharynx } \\
\text { Nasopharynx } \\
\text { Stool }\end{array}$ & $\begin{array}{l}\text { e } \\
\text { e } \\
\text { e } \\
\text { e } \\
\text { f }\end{array}$ \\
\hline D & $\begin{array}{l}\text { Sputum } \\
\text { Nasopharynx } \\
\text { External nares } \\
\text { Stool }\end{array}$ & $\begin{array}{l}\mathrm{g} \\
\mathrm{h} \\
\mathrm{i} \\
\mathrm{g}\end{array}$ \\
\hline
\end{tabular}

infection. Sampling techniques are nontraumatic and inexpensive, but the patient's cooperation is required. The sites with the greatest yield of $P$ aeruginosa are the nasopharynx and oropharynx; as the oropharynx may be contaminated by sputum, however, nasopharyngeal sampling may give a better representation of upper airway infection. Knowledge of the primary site will also permit prospective sampling, to establish when $P$ aeruginosa is acquired and clarify the epidemiology of infection.

A recent report $^{13}$ suggested that aggressive surgical treatment of sinus disease improves lower respiratory symptoms in severely ill adults with cystic fibrosis, suggesting that infection in the upper respiratory tract contributes to the perpetuation of pulmonary sepsis. Controlled prospective studies of treatment targeted at the upper airways are required to establish whether these extrapulmonary sites are clinically important. Treatment of nasal obstruction, with topical corticosteroids or functional endoscopic sinus surgery or both, would facilitate delivery of topical antibiotics. Meanwhile, to protect the donor lungs of transplant recipients with cystic fibrosis from acquiring $P$ aeruginos $a$ from the upper airways, we suggest that these sites are screened for $P$ aeruginosa before operation and that any nasal obstruction is treated, so that delivery of nebulised agents by face mask is facilitated.

The effect of $P$ aeruginosa in the gut on pulmonary infection has not been fully investigated. Recurrent aspiration of gastric contents might occur because of increased oesophageal reflux in patients with cystic fibrosis. ${ }^{14}$ Studies of selective decontamination of the gut to protect against retrograde colonisation of the lungs are in progress.

Our finding of upper airway sites in which $P$ aeruginosa may obtain sanctuary, persisting despite antimicrobial attack, highlights the need for evaluating the treatment of such reservoirs in patients with cystic fibrosis at all stages of their disease.

We thank Dr H Gaya, consultant microbiologist, and the staff of the microbiology department of the Royal Brompton Hospital for their help. We are also grateful to the Frances and Augustus Newman Research Foundation and the Cystic Fibrosis Research Trust for financial support (RFHT and PSN).

1 Govan JRW, Glass S. The microbiology and therapy of cystic fibrosis lung infections. Rev Med Microbio 1990;1:19-28.

2 Lambert HP. Clinical significance of tissue penetration of antibiotics in the respiratory tract. Scand $J$ Infect Dis $1978 ; 14: 262-6$.

3 Kulczycki LL, Wientzen RL, Heller T, Bellanti JA. Factors influencing pseudomonas colonisation in cystic fibrosis. Ann Allergy 1988;60:423-8.

4 Shapiro ED, Milmoe GJ, Wald ER, Rodnan JB, Bowen A. Bacteriology of the maxillary sinuses in patients with cystic fibrosis. $J$ Infect Dis 1982;146:589-93.

5 Cotes JE. Lung function: assessment and application in medicine. Oxford: Blackwell, 1979.

6 King EO, Ward MK, Raney DE. Two simple media for the demonstration of pyocyanin and fluorescin. J Lab Clin Med 1954;44:301-7.

7 Kelly NM, Falkiner FR, Keane CT. Acetamide broth for isolation of $P$ aeruginosa from patients with cystic fibrosis. $J$ Clin Microbiol 1983;17:159.

8 Wolz C, Kiosz G, Ogle JW, Vasil MW, Schaad U, Botzenhart K, Döring G. Pseudomonas aeruginosa crosscolonisation and persistence in patients with cystic fibrosis. Use of a DNA probe. Epidem Infect 1989;102:205-14.

9 Pitcher DG, Saunders NA, Owen RJ. Rapid extraction of bacterial genomic DNA with guanidium thiocyanate. Let Appl Microbiol 1989;8:151-6.

10 Ogle JW, Reller JB, Vasil ML. Development of resistance in $P$ aeruginosa to imipenem, norfloxacin, and ciprofloxacin during therapy: proof provided by typing with a DNA probe. J Infect Dis 1988;157:743-8.

11 Vasil ML, Chamberlain C, Grant CCR. Molecular studies of Pseudomonas exotoxin A gene. Infect Immunol 1986; 52:538-48.

12 Taylor CJ, McGaw J, Howden R, Duerden BI, Baxter PS Bacterial reservoirs in cystic fibrosis. Arch Dis Child 1990;65:175-7.

13 Umetsu DT, Moss RB, King VV, Lewiston NL. Sinu disease in patients with severe cystic fibrosis: relation to pulmonary exacerbation. Lancet 1990;i:1077-8.

14 Cucchiara S, Santamaria F, Andreotti MR, Minella R Ercolini P, Oggero V, et al. Mechanisms of gastrooesophageal reflux in cystic fibrosis. Arch Dis Child 1991;66:617-22. 